\title{
Fungsi Lembaga Penjaminan Simpanan Dalam Membangun Sistem Perbankan Yang Solid Demi Kelangsungan Pembangunan Infrastruktur di Indonesia
}

\author{
The Function of the Deposit Insurance Agency in Building a Solid \\ Banking System for the Continuity of Infrastructure Developmnet in \\ Indonesia
}

\author{
Prawitra Thabib $^{1, a)}$ \& Faizal Kurniawan ${ }^{1, b)}$ \\ ${ }^{1)}$ Departemen Hukum Perdata, Fakultas Hukum, Universitas Airlangga, Surabaya
}

Koresponden : ${ }^{a}$ prawitra@fh.unair.ac.id \& ${ }^{b}$ faizal@fh.unair.ac.id

\begin{abstract}
ABSTRAK
Krisis moneter yang menghantam Indonesia tahun 1998, yang berakibat dilikuidasinya 16 bank, sempat membuat kepercayaan masyarakat pada perbankan menurun. Maka untuk mengatasinya, pemerintah sempat mengeluarkan kebijakan memberikan jaminan untuk seluruh kewajiban bank terhadap nasabahnya, termasuk simpanan masyarakat (blanket guarantee). Kebijakan blanket guarantee terbukti dapat meningkatkan kepercayaan masyarakat terhadap perbankan, melalui sistem perbankan yang solid dan trust masyarakat kepada lembaga bank, maka institusi perbankan dapat memberikan dukungan dalam proyek insfrastruktur di Indonesia, karena dalam setiap pengerjaan proyek infrastruktur pasti membutuhkan dukungan finansial institusi bank. Sejalan dengan hal tersebut, dibutuhkan suatu penyempurnaan perangkat aturan sistem perbankan kedepannya, khususnya dibidang penjaminan simpanan. Penyempurnaan ini bertujuan untuk menciptakan individu bank yang andal dan menciptakan sistem perbankan yang sehat, efisien dan kompetitif, yang diharapkan dapat terhindar dari systemic risk serta dapat mendukung pembangunan infrastruktur di Indonesia.
\end{abstract}

Kata Kunci : Lembaga Penjaminan Sosial, Perbankan dan Proyek Infrastruktur

\section{PENDAHULUAN}

Penyelenggaraan perekonomian di suatu negara tidak terlepas dari penyelenggaraan sistem perbankan di Indonesia, hal ini amatlah penting mengingat fungsi dari perbankan sebagai lembaga intermediasi yang menghubungkan masyarakat yang mempunyai surplus dana kepada masyarakat yang defisit dana. Akan tetapi penyelenggaraan sistem perbankan yang efektif dan efisien saja tidaklah cukup, diperlukan juga suatu sistem yang menjamin simpanan masyarakat yang mempercayakan dananya kepada bank. Wujud kelembagaan penjamin simpanan merupakan perwujudan dari peran serta negara untuk melindungi rakyat, memperbincangkan perlindungan negara. Hal ini dikarenakan ketika negara mengalami krisis masyarakat akan mendapatkan proteksi dari negara sehingga dapat meminimalisir dampak dari suatu krisis. Sebagai contoh krisis moneter yang menghantam Indonesia tahun 1998, yang berakibat dilikuidasinya 16 bank, sempat membuat kepercayaan masyarakat pada perbankan menurun. Maka untuk mengatasinya, pemerintah sempat mengeluarkan kebijakan memberikan jaminan untuk seluruh kewajiban bank terhadap nasabahnya, termasuk simpanan masyarakat (blanket guarantee). Kebijakan blanket guarantee terbukti dapat meningkatkan kepercayaan masyarakat terhadap perbankan, namun ruang lingkup penjaminan yang terlalu 
luas telah membebani keuangan negara dan dapat menimbulkan moral hazard bagi pelaku perbankan dan nasabah. Oleh sebab itu dengan memperhatikan salah satu sisi negatif blanket guarantee dan setelah mempertimbangkan faktor lainnya serta semakin membaiknya kondisi perbankan, kebijakan blanket guarantee akhirnya diputuskan untuk diakhiri. Namun pemerintah menilai bahwa penjaminan simpanan masih tetap diperlukan untuk memelihara kepercayaan masyarakat terhadap perbankan dan meminimalkan risiko yang membebani anggaran negara atau risiko yang menimbulkan moral hazard. Sehingga penjaminan yang sangat luas lingkupnya tersebut diganti dengan sistem penjaminan yang terbatas.

Berdasarkan pengalaman Indonesia pada tahun 1998 tersebut maka dibentuklah Lembaga Penjamin Simpanan (LPS), yaitu lembaga independen yang dibentuk berdasarkan Undang-Undang Nomor 24 Tahun 2004 tentang Lembaga Penjamin Simpanan (UU LPS) yang diubah dengan Undang-Undang Nomor 7 Tahun 2009. UU LPS diundangkan tanggal 22 September 2004 dan mulai berlaku 12 bulan setelah diundangkan, yaitu tanggal 22 September 2005. Dengan berlakunya UU LPS, maka LPS mulai beroperasi sejak tanggal 22 September 2005. Perubahan yang signifikan dalam penjaminan melalui LPS adalah dihapuskannya blanket guarantee, yaitu penjaminan seluruh kewajiban bank, tanpa ada batasan nilai menjadi limited guarantee, yaitu penjaminan secara terbatas. Berdasarkan Undang-Undang tersebut, LPS merupakan lembaga independen yang berfungsi menjamin simpanan nasabah penyimpan dan turut aktif memelihara stabilitas sistem perbankan sesuai kewenangannnya. Simpanan nasabah bank konvensional yang dijamin LPS berbentuk: tabungan, deposito, giro, sertifikat deposito, dan bentuk lainnya yang dipersamakan dengan itu. Selain itu, LPS juga menjamin simpanan nasabah bank syariah yang berbentuk: giro wadiah, tabungan wadiah, tabungan mudharabah dan deposito mudharabah.

\section{ANALISIS}

Lembaga penjamin simpanan atau dikenal dengan istilah deposit insurance dikalangan perbankan dinegara lain sudah lama kenal. Di Amerika Serikat telah dikenal sejak tahun 1993 melalui lembaga Federal Fait Deposit Insurance Corporation (FIDIC). FIDIC adalah suatu lembaga yang akan mengganti dana yang disimpan oleh nasabah bank yang dilikuiditasi. Dengan memberikan jaminan kepada nasabah penyimpanan melalui FIDIC maka dapat dicegah timbulnya kepanikan nasional. Hingga saat ini setiap krisis perbankan di Amerika selalu diselesaikan melalui FIDIC. FIDIC didirikan dengan Banking Act of 1930 dengan tujuan membantu menstabilisasikan sistem perbankan yang pernah mengalami kehancuran akibat depresi ekonomi pada awal 1930-an. Adapun pengalaman beberapa negara dalam hal penjaminan simpanan dapat di temui di Thailand pada krisis tahun 1983, untuk mengatasi hal tersebut pemerintah Thailand melakukan sistem penyelamatan perbankan dengan memberikan bantuan kepada bank yang bersalah melalui dana yang dikumpulkan oleh perbankan (pooling found) untuk perusahaan sekuritas. Pemerintah dan anggota Thai Bankers Assocation (TBA) mendirikan suatu Liquidity Found dengan dana sebesar 5 Miliar Bhat. Dana tersebut digunakan untuk membantu lembaga keuangan yang bermasalah dan dikelola dikelola bersama-sama oleh perwakilan TBA, Kementrian keuangan, dan Bank of Thailand (BOT). Pada tahun 1985 ketika kehilangan kepercayaan masyarakat terhadap lembaga keuangan makin serius dibentuk The Financial Institution Devolepment Found (FIDF). Sementara itu di Jerman, bentuk penjaminan simpanan diaplikasikan melalui asuransi simpanan bagi bank swasta didirikan oleh German Bank Assocation untuk meng-offset keuntungan kompetitif yang dimiliki oleh saving bank yang dimilki oleh pemerintah. Kelompok saving bank memiliki beberapa skim asuransi regional dan skim asuransi nasional. Sekedar informasi penjamin simpanan di Jerman merupakan tertinggi didunia, baik dalam hal absolut maupun jika dibandingkan dengan simpanan perkapita Rata-Rata batas cakupan penjamin adalah tiga kali per kapita GDB. Sementara di Indonesia LPS sudah dimulai tahun 1998, ketika krisis 
moneter dan perbankan yang menghantam Indonesia, berlangsung. . Untuk mengatasi krisis yang terjadi, pemerintah mengeluarkan beberapa kebijakan diantaranya memberikan jaminan atas seluruh kewajiban pembayaran bank, termasuk simpanan masyarakat (blanket guarantee). Hal ini ditetapkan dalam Keputusan Presiden Nomor 26 Tahun 1998 tentang Jaminan Terhadap Kewajiban Pembayaran Bank Umum dan Keputusan Presiden Nomor 193 Tahun 1998 tentang Jaminan Terhadap Kewajiban Pembayaran Bank Perkreditan Rakyat.

Akan tetapi krisis pada tahun 1998 bukanlah krisis terakhir bagi Indonesia, pada tahun 2008 muncul krisis ekonomi yang melanda berbagai negara termasuk Indonesia, akan tetapi krisis ekonomi pada tahun 2008 tidaklah sama dengan krisis pada tahun 1998, hal ini dikarenakan Krisis ekonomi global yang terjadi pada tahun 2008 sebenarnya bermula pada krisis ekonomi Amerika Serikat yang lalu menyebar ke negara-negara lain di seluruh dunia, termasuk Indonesia. Krisis ekonomi Amerika diawali karena adanya dorongan untuk konsumsi (propincity to Consume). Rakyat Amerika hidup dalam konsumerisme di luar batas kemampuan pendapatan yang diterimanya. Mereka hidup dalam hutang, belanja dengan kartu kredit, dan kredit perumahan. Akibatnya lembaga keuangan yang memberikan kredit tersebut bangkrut karena kehilangan likuiditasnya, karena piutang perusahaan kepada para kreditor perumahan telah digadaikan kepada lembaga pemberi pinjaman. Pada akhirnya perusahaan perusahaan tersebut harus bangkrut karena tidak dapat membayar seluruh hutang-hutangnya yang mengalami jatuh tempo pada saat yang bersamaan.

Runtuhnya perusahaan-perusahaan finansial tersebut mengakibatkan bursa saham Wall Street menjadi tak berdaya, perusahaan-perusahaan besar tak sanggup bertahan seperti Lehman Brothers dan Goldman Sachs. Krisis tersebut terus merambat ke sektor riil dan nonkeuangan di seluruh dunia. Krisis keuangan di Amerika Serikat pada awal dan pertengahan tahun 2008 telah menyebabkan menurunnya daya beli masyarakat Amerika Serikat yang selama ini dikenal sebagai konsumen terbesar atas produk-produk dari berbagai negara di seluruh dunia. Penurunan daya serap pasar itu menyebabkan volume impor menurun drastis yang berarti menurunnya ekspor dari negara-negara produsen berbagai produk yang selama ini dikonsumsi ataupun yang dibutuhkan oleh industri Amerika Serikat. Oleh karena volume ekonomi Amerika Serikat itu sangat besar, maka sudah tentu dampaknya kepada semua negara pengekspor di seluruh dunia menjadi serius pula, terutama negara-negara yang mengandalkan ekspornya ke Amerika Serikat.

Untuk mengatasi kemungkinan-kemungkinan krisis yang melanda suatu negara maka diperlukan adanya suatu sistem yang dapat melakukan perlindungan hukum bagi nasabah penyimpan dana yang tepat untuk mengatasi suatu krisis ekonomi. Adapun memperbincangkan bentuk perlindungan hukum terhadap nasabah penyimpan dana dapat dikategorikan kedalam dua bentuk yaitu Perlindungan secara tidak langsung dan perlindungan hukum secara langsung. Adapun yang dimaksud dengan perlindungan secara tidak langsung, adalah suatu perlindungan hukum yang diberikan kepada nasabah penyimpan dana terhadap segala risiko kerugian yang timbul dari suatu kebijaksanaan atau timbul dari kegiatan usaha yang dilakukan oleh bank, hal ini diwujudkan dalam suatu tindakan pencegahan yang bersifat internal yang dilakukan oleh bank yang bersangkutan berupa penerapan prinsip kehati-hatian, penerapan Batas Maksimum Pemberian Kredit (BPMK), kewajiban mengumumkan neraca dan perhitungan laba rugi dan pelaksanaan merger, konsolidasi dan akuisisi bank. Sementara itu perlindungan secara langsung adalah suatu bentuk perlindungan yang diberikan langsung kepada nasabah penyimpan terhadap kemungkinan timbulnya risiko kegiatan usaha bank, yang diwujudkan dalam upaya; pemberian hak preferen kepada nasabah dan lembaga asuransi deposito.

Perlindungan yang diberikan oleh LPS dalam menjamin simpanan masyarakat amatlah penting, hal ini merupakan pengaplikasian dari tujuan utama dari perbankan Indonesia untuk menunjang pelaksanaan pembangunan nasional, dalam rangka meningkatkan pemerataan 
pertumbuhan ekonomi dan stabilitas nasional kearah peningkatan kesejahteraan rakyat, melalui skema intermediary yaitu menghimpun dan menyalurkan dana kepada masyarakat. Exit policy bank sebagaimana yang telah diatur dalam Pasal 37 angka 2 dan 3 Undang Undang perbankan merupakan upaya terakhir yang dapat dilakukan oleh Bank Sentral, hal ini disebabkan likuidasi dapat menimbulkan dampak negatif bagi sistem perekonomian nasional, karena berkaitan dengan kepercayaan publik. Sehingga dapat dipahami suatu otoritas perbankan hendaknya tidak dengan mudahnya melikuidasi suatu bank, mengingat dampak dari adanya suatu likuidasi, yang mana dalam hal ini harus memperhatikan segala aspek yang dapat menyehatkan bank, inilah ruh utama dari LPS dalam menjaga iklis stabilitas ekonomi nasional, penekanannya tidak hanya sebatas likuidasi bank, namun lebih dari itu LPS diharapkan dapat melakukan upaya penyehatan bank - bank bermasalah demi melindungi kepentingan nasabah, sehingga diharapkan upaya penyehatan bank akan berimbas pula pada perlindungan nasabah, yang secara tidak langsung juga akan menjaga stabilitas ekonomi nasional.

\section{PENUTUP}

Pentingnya fungsi LPS dalam memelihara stabilitas sistem perbankan telah melahirkan kewenangan atribusi bagi LPS untuk merumuskan kebijakan dalam memelihara stabilitas sistem perbankan, merumuskan, menetapkan dan melaksanakan kebijakan penyelesaian bank gagal yang tidak berdampak sistemik dan melaksanakan penanganan bank gagal yang berdampak sistemik. Oleh sebab itu formulasi kebijakan dalam upaya menjaga stabilitas ekonomi harus segera dilakukan pembaharuan dan penyempurnaan, mengingat sangat kompleksnya persoalan yang dapat timbul dalam kegiatan ekonomi global. Undang-undang telah memberi kewenangan bagi LPS untuk merumuskan dan menetapkan kebijakan, sebagai upaya preventif dan represif dalam menangani bank gagal maupun dalam upaya pemeliharaan stabilitas perbankan, melalui intrumen penjaminan dana masyarakat.

\section{DAFTAR PUSTAKA}

Hermansyah (2005). "Hukum Perbankan Nasional Indonesia". Hukum Perbankan Nasional Indonesia. Jakarta.

UU 9/16. Undang - undang No. 9 Tahun 2016 tentang Pencegahan dan Penanganan Krisis Sistem Keuangan.

UU 7/09. Undang - undang No. 7 Tahun 2009 tentang Penetapan Peraturan Pemerintah Pengganti Undang - Undang Nomor 24 Tahun 2004 tentang Lembaga Penjamin Simpanan Menjadi Undang - Undang.

PP 3/08. Peraturan Pemerintah Penganti Undang-Undang Republik Indonesia Nomor 3 Tahun 2008 Tentang Perubahan Atas Undang - Undang Nomor 24 Tahun 2004 tentang Lembaga Penjamin Simpanan.

UU 24/04. Undang - undang No. 24 Tahun 2004 tentang Lembaga Penjamin Simpanan.

UU 10/98. Undang-Undang Nomor 10 Tahun 1998 tentang Perubahan Atas Undang undang Nomor 7 Tahun 1992 Tentang Perbankan.

UU 7/92. Undang - undang Nomor 7 Tahun 1992 Tentang Perbankan.

http://winiez.com/2017/05/06/lembaga-penjamin-simpanan-di-negara-lain/ diakses pada tanggal 17 Agustus 2018.

https://elsaryan.wordpress.com/2009/09/08/krisis-ekonomi-global-2008-serta-dampaknyabagi-perekonomian-indonesia/, diakses pada tanggal 17 Agustus 2018. 